Cumhuriyet University

Journal of Economics and Administrative Sciences

E-ISSN: 2687-4032

2021, 22(2), pp.480-503.

Doi: $10.37880 /$ cumuiibf.1009235

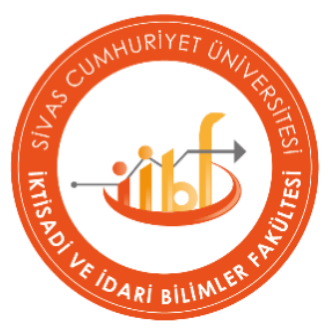

\title{
HOW DO DEFAULTS AFFECT BEHAVIOR OF INDIVIDUAL RETIREMENT: EVIDENCE FROM ANKARA ${ }^{1}$
}

\author{
Havva SERIM' ${ }^{2}$ \\ Fahriye ÖZTÜRK ${ }^{3}$
}

\begin{abstract}
One of the most fundamental goals that both individuals and countries strive to achieve is to increase savings. Behavioral economics, which has recently enriched economic analysis with insights from psychology, offers important insights and policies on saving behavior in this context. Because saving requires willpower, planning, and attention, and therefore a decision with a high cognitive cost, behavioral economics makes use of default options to facilitate saving, especially for retirement. By breaking the inertia with these automatic strategies, people who want to be included in retirement plans but cannot be due to behavioral barriers are included in the system. Turkey is one of the few countries that has introduced national-level automatic enrollment in private pension systems to encourage people to save for retirement. Although the policy's effectiveness is debatable, it is fair to conclude that it has accelerated enrolment in individual pension plans. This is because defaults have a significant impact on saving behavior. However, there are few empirical data that explain how defaults operate. To find out, we created a survey for Ankara public employees to explore possible demographic, financial, and behavioral constructs for automatic enrollment choices. Then, logistics regression analysis was conducted based on 434 survey data obtained from employees of different public institutions and organizations in Ankara. Gender, marital status, and the number of dependents in the family all have an impact on the decisions. The other significant findings concern behavioral constructs: Ankara public employees who find individual pension systems complex are more likely to opt out, and the public authority endorsement effect greatly reduces the risk of quitting the system. These findings show that there is a need for more educational and informational efforts on the pension system, and that policymakers have a significant amount of responsibility as a result of this strategy.
\end{abstract}

\author{
Article History: \\ Date submitted: \\ 13 October 2021 \\ Date accepted: \\ 24 October 2021
}

\section{Jel Codes:}

D9, D14, H3

Keywords:

Default Options, Individual Retirement, Saving Behavior, Behavioral Economics

Suggested Citation: Serim, H. \& Ozturk, F. (2021). How Do Defaults Affect Behavior of Individual Retirement: Evidence from Ankara. Cumhuriyet University Journal of Economics and Administrative Sciences, 22(2), 480503.

\footnotetext{
${ }^{1}$ This article was prepared from Phd Thesis named "Saving Behaviour in Behavioural Economics: An Analysis Specific to Default Options and Individual Pension System" written by Havva Serim under the supervision Prof. Dr. Fahriye Oztürk.

${ }^{2}$ Res. Assist. Dr., Ankara Hacı Bayram Veli University, Faculty of Economics and Administrative Sciences, Department of Economics, havva.serim@hbv.edu.tr, ORCID ID: 0000-0003-4222-4670

3 Prof. Dr., Ankara Hacı Bayram Veli University, Faculty of Economics and Administrative Sciences, Department of Economics, fahriye.ozturk@hbv.edu.tr, ORCID ID: 0000-0002-2534-8479
} 
Cumhuriyet Üniversitesi

Iktisadi ve Idari Bilimler Dergisi

E-ISSN: 2687-4032

2021, 22(2), pp.480-503.

Doi: 10.37880/cumuiibf.1009235

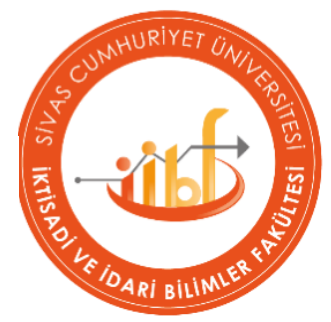

\section{ÖNTANIMLI SEÇENEKLER BİREYSEL EMEKLILIIK DAVRANIŞINI NASIL ETKILEMEKTEDİR: ANKARA ÖRNEĞ ${ }^{1}$}

\section{Havva SERİM ${ }^{2}$ \\ Fahriye ÖZTÜRK ${ }^{3}$}

$\ddot{\mathbf{O} z}$

Hem kişilerin hem de ülkelerin ulaşmaya çalıştığı temel hedeflerden biri tasarrufları artırmaktır. Son zamanlarda, psikolojiden aldığı içgörülerle iktisadi analizi zenginleştiren davranışsal iktisat ise bu bağlamda tasarruf davranışına iliş̧kin önemli içgörüler ve politikalar sunmaktadır. Tasarrufun irade gücü, planlama ve dikkat gerektirmesi ve dolayısıyla bilişsel maliyeti yüksek bir karar olması nedeniyle, davranışsal iktisat özellikle emeklilik için tasarrufu kolaylaştırmak için öntanımlı seçeneklerden yararlanmaktadır. Söz konusu otomatik stratejilerle ataletin kırılması sağlanarak, emeklilik planlarına dahil olmak isteyen ancak davranışsal engeller nedeniyle olamayan kişiler sisteme dahil edilmektedir. Bu bağlamda, otomatik stratejileri ülke çapında uygulayan birkaç ülkeden biri olan Türkiye'nin de deneyimi dikkat çekmektedir. Türkiye'de bireysel emeklilikte otomatik katılım stratejisininin, planlara dahil olma oranlarını, beklendig $i$ kadar olmasa da arttırdığını söylemek mümkündür. Bu noktada, öntanımlı seçeneklerin tasarruf davranışı üzerinde nasıl etkili olduğu sorusu önem kazanmaktadır. Ancak bu etkinin nasıl gerçekleştiğini araştıran çalışmaların sınırlı olduğu görülmektedir. Buradan hareketle çalışma, Ankara kamu çalışanları örneklemi üzerinden, bireysel emeklilik sistemine otomatik katılım tercihlerini açılamada etkili olduğu düşünülen demografik, finansal ve davranışsal değişkenleri tespit etmeye odaklanmaktadır: Ankara'daki farklı kamu kurum ve kuruluş çalışanlarından sağlanan 434 anket verisinden yola çıkılarak, lojistik regresyon analizi yapılmıştır. Analiz sonucunda demografik değişkenlerden cinsiyet, medeni durum ve hanede bakmakla yükümlü olunan kişi sayısının; davranışsal değişkenlerden ise karmaşıklık algısı ile kamu otoritesi tasdik etkisinin tercihlerde etkili olduğu bulunmuştur. Davranışsal iktisadın teorik öngörüsünün aksine, bireysel emeklilik planları karmaşık bulundukça, sistemden çıkma olasılığının arttı̆̆ görülmüştür. Diğer yandan, stratejinin kamu otoritesi tarafindan verilen bir tavsiye olarak algilanmasinın sistemden çıkma olasılı̆̆ını azalttı̆̆ bulgusu, ilgili stratejilerin politik karar alıcılara önemli bir sorumluluk yüklediğini ortaya koymaktadır.
Makale Geçmişi:

Iletilen Tarih:

13 Ekim 2021

Kabul Tarihi:

24 Ekim 2021

\section{Jel Kodlart:}

D9, D14, $H 3$

Anahtar Kelimeler:

Öntanımlı Seçenekler,

Bireysel Emeklilik,

Tasarruf Davranışı,

Davranışsal İktisat

Önerilen Alıntı: Serim, H., \& Öztürk, F. (2021). Öntanımlı Seçenekler Bireysel Emeklilik Davranışını Nasıl Etkilemektedir: Ankara Örneği. Cumhuriyet Üniversitesi İktisadi ve İdari Bilimler Dergisi, 22(2), 480-503.

\footnotetext{
${ }^{1} \mathrm{Bu}$ çalışma Prof. Dr. Fahriye Öztürk danışmanlığında Havva Serim tarafından hazırlanan “Davranışsal İktisatta Tasarruf Davranışı: Öntanımlı Seçenekler ve Bireysel Emeklilik Sistemi Özelinde Bir Analiz” adlı yayınlanmamış doktora tezinden üretilmiştir.

${ }^{2}$ Arş. Gör. Dr., Ankara Hacı Bayram Veli Üniversitesi, İktisadi ve İdari Bilimler Fakültesi, İktisat Bölümü, havva.serim@hbv.edu.tr, ORCID ID: 0000-0003-4222-4670

${ }^{3}$ Prof. Dr. Ankara Hacı Bayram Veli Üniversitesi, İktisadi ve İdari Bilimler Fakültesi, İktisat Bölümü, fahriye.ozturk@hbv.edu.tr, ORCID ID: 0000-0002-2534-8479
} 


\section{HOW DO DEFAULTS AFFECT BEHAVIOR OF INDIVIDUAL RETIREMENT: EVIDENCE FROM ANKARA}

\section{INTRODUCTION}

Default options are one of the most widely applied nudges, both in other economics fields and saving behavior (Johnson et.1993; Johnson and Goldstein, 2003; McCalley, 2006; Sunstein and Reisch, 2016). By choice architectures, those options predetermine what happens if people do not make a choice or act on the subject while preserving the freedom of choice of (rational) people who believe that they make the best choice for them (Sunstein, 2014; 2017a; Thaler and Sunstein, 2008: 81-87). This nudge is applied in line with theoretical insights of behavioral economics. That is, behavioral economics rejects the assumption that individuals will always choose the option that will maximize their own utility in a rational manner, regardless of the design of the decision problem, when the transaction costs are zero or close to zero (Rooij and Teppa, 2014). However, in situations where people can't make the best decision due to bounded rationality, inertia or procrastination, the design of the decision problem and so default options matter. One of the clearest indications that people's preferences are not independent from the design of the decision problem is the individual pension system applications of the default options.

Encouraging individual pension systems are important due to both its macroeconomic outputs such as increasing total savings and easing the burden on the younger population and microeconomic outputs such as maintaining current living standards during retirement periods. However, despite the importance of the individual pension system for employees, many employees do not make enough use of the private pension opportunities provided by their employers or start saving for retirement too late. In this context, many automatic strategies using default options like automatic enrollment, automatic escalation and automatic portfolio allocation are developed to increase employee participation and savings in the private pension system (Madrian ve Shea, 2001; Choi et. 2002; 2004; Mitchell and Utkus, 2004; Benartzi and Thaler, 2007; Madrian, 2012). Thus, default options applied in the private pension system might help people to execute the savings they want to make automatically without having to think constantly about the issue.

So, why those default options on saving behavior are effective? Behavioral economics findings suggest many insights related to complex decision environment, inertia and procrastination, endorsement effect, loss aversion, anchoring and cognitive dissonance. When the decision problem is complex such as in pension plans, people are unsure of what to do and they usually stick with the default option (Beshears et. 2008; Sunstein, 2017b). People often don't get a job done today if they have the opportunity to postpone it tomorrow. As a matter of fact, many employees state that they want to save via a private pension system, but they postpone opting in (Madrian and Shea 2001; Choi et. 2002; 2004; Beshears et. 2008; Rudolph, 2016). Default options also affect individual retirement saving decisions, as people see these options as a certain approved course of action. To put it in another way, when participation in the private pension system is automatic, people may consider this as a sign that participation is a good idea. Moreover, default options introduce new reference points, so change people's perceptions of gain and loss (Sunstein, 2017b: 602) and anchor their beliefs (Goda et. 2014; Beshears et. 2018). Finally, when people find themselves participated in the private pension system by default, they can generate justifications that this is a good choice for them and therefore they continue to opt in. They also report that when they are automatically enrolled in the savings plan, their willingness to save had increased when they realized that they could save. This, in a way, means that the dissonance in behavior-thinking is resolved (Blumenstock et al.2018; Beshears et. 2018).

In accordance with those insights, automatic strategies are implemented in many countries to encourage private pension plans under the soft compulsion policies. The policy of automatic 


\section{Havva SERİM \& Fahriye ÖZTÜRK, 2021 Cilt: 22, Sayl: 2, ss.480-503.}

enrollment in the private pension system was first implemented in the USA and UK as employer sponsored. While those kinds of implementations continue, New Zealand, Italy, UK and Turkey's experiences draw attention since those are the countries that have implemented automatic enrollment at nationwide. The implementation of the policy at national level differs from employersponsored practices specific to the company in terms of amount and form of the incentives, and country-specific economic conditions (OECD, 2009; Rinaldi, 2011). Turkey, as one of the countries that have adopted behavioral approaches in public policy, started to implement Auto Enrollment System (AES) on January 1, 2017. By this policy, public and private employees under the age of 45 were gradually opted in individual pension savings system and they were granted the right to opt out within two months at no cost (Pension Monitoring Center, 2018: 12-13; Turkish Ministry of Economy, 2018: 127). $78 \%$ of public and $85 \%$ of private employees did not have any individual retirement contract when they were opted in the system, and it is seen that $41 \%$ and $33 \%$ of them continue to stay in after the policy, respectively (Pension Monitoring Center, 2019). We see two prominent outcomes here. First, although opt in rates are low, AES policy gathered momentum in terms of introducing employees to the system who did not have a private pension contract before. Second, the fact that opt in rates in public sector are higher than private sector indicates that there might be a difference in the preferences for automatic enrollment between two sectors. Starting from this, we designed a survey for Ankara public employees to identify potential demographic, financial and behavioral explanations for automatic enrollment choices. Thus, we could understand the mechanism behind the default options and design better policies.

The remainder of this paper is organized as follows. In Section 2, we summarized the relevant literature. Section 3 describes the context and our sources of data and estimation technique. Section 4 present the results of our survey and the model. Section 5 concludes the paper.

\section{LITERATURE REVIEW}

It seems that research in individual retirement system (IRS) implementations of default options focus more on results/success of the policy. The post-policy situation is monitored, and focus is on how to develop default options more effectively regarding contribution rates and portfolio distribution (Madrian ve Shea, 2001; Choi et. 2002; 2004; Mitchell and Utkus, 2004; Benartzi and Thaler, 2007; Carroll et. 2009; Madrian, 2012; Chetty et. 2014). On the other hand, as the success of the policy is monitored, the mechanisms behind the policy started to get attention to design better ones. In other words, the question of where the effects of these options stem from has become more evident. However, there is limited empirical research on this subject. The leading few studies consider which personal, decisional, and behavioral characteristics besides economic and demographic ones make default options effective.

Rooij and Teppa (2014), based on the hypothesis that economic decisions such as private pension and non-economic decisions such as organ donation are affected by designing of opt in and opt out ways, researched the relationship of this effect and personal characteristics. In addition to personal characteristics like procrastination, advice seeking, inertia and endorsement, they analyze socio-economic variables such as age, education, income, and financial literacy for households in Netherlands. According to their survey and probit regressions results, there is no relationship between personal characteristics and sticking with default option. On the other hand, financial literacy, age, and income increase the likelihood of enrollment of voluntary pension plans. Accordingly, the authors suggest that making complex economic decisions like private pension 


\section{HOW DO DEFAULTS AFFECT BEHAVIOR OF INDIVIDUAL RETIREMENT: EVIDENCE FROM ANKARA}

plans easy to understand through education could support active financial decision making. Brown et al. (2016) assessed the difference in responses to default options in the public pension plan trough decision-making approaches, economic and demographic characteristics. For their study, they conducted survey research with university employees of state of Illinois in US. When these employees opt in State University Pension System (SURS), they have to choose from three public pension plans; if they do not make a choice within 6 months, they are automatically enrolled in standard plan which is one of three plans. So, the study researched the decision-making approaches of people who were opted in standard plan by default because they did not make a choice actively. Procrastination is found to be one of the most important determinants of automatic enrollment. ${ }^{1}$ While vigilance and hypervigilance aren't significant, buck-passing is significant in explaining default. Also, people with the need for high cognitive closure, in other words, people who wish to find an answer to eliminate uncertainty about an issue are less likely to be opted in default options. Those with higher financial literacy, higher education, income, and wealth, and also women are less likely to opt in default options. Given the important role of procrastination behavior on effect of default options, the study highlights the need to be careful about the design of default options, especially where in cases preferences can't be changed afterwards. Goda et al. (2018) use the data from US Office of Personnel Management regarding individual retirement plans, based on survey questions. They try to elicit present-bias, financial literacy and exponential growth bias which is related again financial literacy and then analyze these for two different enrollment cases: active enrollment and automatically being enrolled in the plan. They found that present time bias or procrastination has an important role in explaining why people fail to actively enroll in the plan, to maximize saving opportunities such as employer contribution and tax relief. Accordingly, presentbias determines whether to continue to save at the default contribution rate under automatic enrollment. On the other hand, the authors assert that financial literacy and exponential growth bias are significant in explaining the decisions that require active enrollment. In this regard, they emphasize the importance of policy interventions that reduce the effects of present-bias, financial illiteracy, and exponential growth bias. Blumenstock et al. (2018), in a field experiment with employees of Roshan, the largest mobile network operator in Afghanistan, examine the default options designed for the six-month contracted savings account and different rates of employer contribution (the effect of financial incentives), unlike other studies searching for private pension. Roshan employees are automatically enrolled in the savings account called M-Pasandaz, which uses mobile money. Half of the employees' salaries are deducted as 5\% each month to be transferred to M-Pasandaz accounts, while for other half this rate is set to $0 \%$. All employees have the right to change their contribution rates at any time and employees received regular reminder messages and education on the subject. Thus, factors such as endorsement effect, the complex perception of the decision problem or ignorance/ inattention of the participants could be observed. While finding that the aforementioned factors didn't play a role on the effect of default options, the researchers indicate that procrastination caused by present-bias for contribution rate decisions, made default options effective. As such, they find that those enrolled in the savings account with $5 \%$ default rate, contribute $40 \%$ more than those enrolled in at $0 \%$ rate. They observe that, this is equivalent to the impact of a $50 \%$ financial incentive provided by the employer. From this point of

\footnotetext{
${ }^{1}$ Brown and Previtero (2014), in other indirectly related study, classifies those who enrolled in the health plan offered by the company as deferred on the last possible day, found that those who postpone are more likely to continue with default contribution and portfolio allocation option.
} 


\section{Havva SERİM \& Fahriye ÖZTÜRK, 2021 Cilt: 22, Sayl: 2, ss.480-503.}

view, the authors argue that it would be successful to automate default contributions/salary deductions in individual pension schemes.

For Turkey, to the knowledge of the resseearchers, we couldn't encounter research on which factors were effective on automatic participation in IRS through the lenses of behavioral economics. However, there are two studies offering samples from Isparta, which examine the views of those who opt in and opt out the IRS considering automatic participation. In addition, Aydin and Selçuk (2017) search the determinants of opt in preferences for the scenario that automatic enrollment policy would be switched; also, considering the psychological factors, Aksoy (2019) analyzes the effect of demographic variables on opt in and opt out decisions after AES implemented. First study from Isparta, Gülay et al. (2017), make a survey with academicians before the policy and the second one, Kocabıyık ve Küçükçakal (2018) analyze both public and private sector employees' views after the policy. Both studies assert that $25 \%$ state subsidy is prominent factor of opt in decision and finding 3\% contribution rate high and preference to save in other financial devices other than IRS are leading in opt out decision. Also, income and education level and gender were significant. Aydın and Selçuk (2017) in their survey study conducted with 130 people via e-mail, try to find out whether socio-demographic characteristics, financial literacy, and psychological factors such as future time perspective, locus of control and regulatory focus are effective in the decision of opt in after automatic enrollment. They found that focus on present (low future-time perspective) increases the likelihood of opt out the system. On the other hand, the opt in decision is highly determined by the ownership of any private pension contract before the policy since those people had developed a positive attitude towards the plan (experienced the gains from a system similar to the present one). Lastly, Aksoy (2019) identifies that women, young, single, low-income, and poorly educated people opt in more likely than relevant groups, from her survey study with 374 people under the age of 45 . She explains that the only explanatory variable that is found to be statistically significant in the model estimation made by logistic regression is education level, by the fact that people with high education levels are aware of the low return on private pension funds in the past years and this group has the knowledge to manage their own savings. Therefore, the author suggests focusing on the management and control of the relevant funds to increase confidence in private pension system.

\section{DATA SET AND METHODS}

In line with the review of the relevant literature, we aimed to understand the effect of sociodemographic variables, financial literacy, and behavioral constructs on IRS decisions of the public employees in Ankara after $\mathrm{AES}^{2}$. The data were collected from employees in May 2019 through face-to-face survey. The questionnaire consists of three parts. First part has questions and statements to obtain socio-demographics and views about opt in or opt out decisions like the studies of MacLeod et al.2012, Gülay et al. 2017, Kocabıyık and Küçükçakal, 2018. Second part consists of financial literacy questions based on the study of Lusardi and Mitchell (2005). Third part consists

\footnotetext{
${ }^{2}$ Hence, public and private sector employees have different behaviors due to differences in motivation, personality traits and working conditions (Özdevecioğlu, 2002; Willem et al. 2007). For this reason, the study focused only on public employees, and in this direction, Ankara was selected as the province where public employees are concentrated.
} 


\section{HOW DO DEFAULTS AFFECT BEHAVIOR OF INDIVIDUAL RETIREMENT: EVIDENCE FROM ANKARA}

of 4 variables in 5-point Likert scale to determine behavioral constructs ${ }^{3}$. Those variables are complexity perception, buck-passing, procrastination, and public authority endorsement effect that is developed by drawing on the studies of MacLeod et al.2012, Mann et.al 1997; Brown et. al, 2016 and Brown et. al 2012, respectively.

The number of public employees in Ankara are 366,277 and public employees are mostly concentrated in Ankara (State Personnel Presidency, 2018: 15). In this regard, although the sample group of the study is limited to make generalization at national level, analyzing Ankara public employees' views and behaviors would give important insights regarding the subject. The other limitation of the study is related to sample selection. It was impossible to use random-sampling method due to the personal data protection law. For this reason, we used the maximum variation sampling which is a purposive sampling technique by interviewing with employees under the age of 45 from various public institutions and organizations (Özen ve Gül, 2007; Palinkas et.al 2015; Alvi, 2016). Then, we were provided 434 questionnaire data, which were filled in. Table 1 gives the descriptive statistics of the study. We see from Table 1 that opt out rate is high in line with nationwide data. On the other hand, participants who stayed in mostly stick with default options for contribution rate and portfolio allocation.

Table 1: Descriptive Statistics Regarding Demographic Variables and Opt in/Opt out Decision of AES

\begin{tabular}{|c|c|c|c|}
\hline & & $\mathrm{n}$ & $\%$ \\
\hline \multirow{2}{*}{ Gender } & Woman & 209 & $48,2 \%$ \\
\hline & Man & 225 & $51,8 \%$ \\
\hline \multirow{4}{*}{ Age } & Under and 30 & 117 & $27,0 \%$ \\
\hline & $31-35$ & 130 & $30,0 \%$ \\
\hline & $36-40$ & 115 & $26,5 \%$ \\
\hline & $41-45$ & 72 & $16,6 \%$ \\
\hline \multirow{2}{*}{ Marital Status } & Married & 281 & $64,7 \%$ \\
\hline & Single & 153 & $35,3 \%$ \\
\hline \multirow{3}{*}{ Number of dependents } & None & 164 & $37,8 \%$ \\
\hline & $1-2$ & 181 & $41,7 \%$ \\
\hline & Over and 3 & 89 & $20,5 \%$ \\
\hline \multirow{3}{*}{ Education level } & Highschool & 21 & $4,9 \%$ \\
\hline & College/University & 296 & $68,2 \%$ \\
\hline & Postgraduate & 117 & $27,0 \%$ \\
\hline Income level & Under and $4000 \mathrm{TL}$ & 66 & $15,2 \%$ \\
\hline
\end{tabular}

3 The use of these variables as "scales" was found to be appropriate because of the statistical tests. On the other hand, the study does not claim that scales were developed because all steps of scale development were not followed, and these variables were not tested for different samples yet. In this respect, the variables obtained have potential to be developed as scales. 
Havva SERIM \& Fahriye ÖZTÜRK, 2021 Cilt: 22, Sayı: 2, ss.480-503.

\begin{tabular}{llll}
\hline & $4001-6000 \mathrm{TL}$ & 104 & $24,0 \%$ \\
\cline { 2 - 4 } & $6001-8000 \mathrm{TL}$ & 96 & $22,1 \%$ \\
\cline { 2 - 4 } & $8001-10000 \mathrm{TL}$ & 85 & $19,6 \%$ \\
\cline { 2 - 4 } Decision of IRS with AE & Over 10000 TL & 83 & $19,1 \%$ \\
\hline \multirow{2}{*}{ Contribution rate in IRS contract } & Opt in & 276 & $63,6 \%$ \\
\cline { 2 - 4 } & Opt out & 26 & $16,5 \%$ \\
\hline \multirow{2}{*}{ Portfolio allocation in IRS contract } & Default option & 132 & $83,5 \%$ \\
\cline { 2 - 4 } & My active decision & 38 & $24,1 \%$ \\
\cline { 2 - 4 } & Default option & 120 & $75,9 \%$ \\
\hline
\end{tabular}

According to the answers, main reasons for opting in are: it's an opportunity for me to save, I find $25 \%$ state subsidy encouraging and monthly contribution rate is suitable for my budget. $25 \%$ state subsidy was also found to be important in Gülay et. al (2017) and Kocabıyık and Küçükçakal (2018). Again, main reasons for leaving the system are: I am concerned about the returns of my savings in this system and I am already saving in different ways for retirement

The data analysis was made with SPSS 24.0. For financial literacy level test, we calculated item discrimination and item difficulty index. In addition to this, we calculated Cronbach's Alpha and KR-20 coefficients to determine internal consistency. Also, exploratory factor analysis was calculated to determine the construct validity of the scales related to behavioral constructs, and Cronbach's Alpha coefficient for the reliability level. Then, by considering opt in or opt out decision as a dependent binary variable and other aforementioned independent variables, we analyzed the results of logistic regression model.

\section{RESULTS AND DISCUSSION}

To measure financial literacy, we asked three general (Lusardi and Mitchell, 2005) and two specific questions related to Turkey's IRS system. Table 2 shows item analysis for these questions. So, none of the questions are excluded. Also, financial literacy variable is found to be reliable according to Cronbach's Alpha $(0,627)$ and KR-20 $(0,629)$.

Table 2: Item Difficulty and Discrimination Index for Financial Literacy

\begin{tabular}{|c|c|c|}
\hline Item & Item Difficulty Index (p) & Item Discrimination Index (r) \\
\hline Question 1 & 0,80 & 0,15 \\
\hline Question 2 & 0,76 & 0,21 \\
\hline Question 3 & 0,64 & 0,28 \\
\hline Question 4 & 0,48 & 0,26 \\
\hline Question 5 & 0,49 & 0,30 \\
\hline
\end{tabular}




\section{HOW DO DEFAULTS AFFECT BEHAVIOR OF INDIVIDUAL RETIREMENT: EVIDENCE FROM ANKARA}

As stated earlier, in line with the relevant behavioral economics literature procrastination, complexity perception, buck passing, and public authority endorsement effect variables were analyzed. Analyzes regarding the statistical relevance of using the variables at hand as 4 separate scales were made by KMO and Bartlett test, scatter plot of eigenvalues and the varimax rotation process. Note that these variables might not be called as "scales" since not all the steps to develop scales were followed such as testing for different samples. However, as we follow from factor analysis results, these 4 variables are statistically significant to be used as a 4-separate scale. Also, there is no strong correlation between these independent variables. ${ }^{4}$

Table 3: Descriptive Statistics of Financial Literacy and Behavioral Variables

\begin{tabular}{llllll}
\hline & N & Minimum & Maximum & Avr. & sd \\
\hline Financial Literacy Level & 434 & 0,00 & 100,00 & 63,50 & 29,38 \\
\hline Procrastination & 434 & 1,00 & 5,00 & 2,37 & 0,88 \\
\hline Complexity Perception & 434 & 1,00 & 5,00 & 2,29 & 0,87 \\
\hline Buck Passing & 434 & 1,00 & 5,00 & 1,92 & 0,74 \\
\hline Public Authority Endorsement Effect & 434 & 1,00 & 5,00 & 2,23 & 0,89 \\
\hline
\end{tabular}

After we get statistically relevant results for independent variables, we estimated logistic regression model ${ }^{5}$. Least $-2 \mathrm{LL}$ value is attained with all aforementioned variables. Cox\&Snell R2 revealed that the logistic model could explain $10 \%$ of variance in the dependent variable and Nagelkerke R2 revealed that the model could explain approximately $14 \%$ of variance in the dependent variable. Table 4 gives logistic regression results.

Table 4: Logistic Regression Results

\begin{tabular}{llcccccc}
\hline & B & Se & Wald & df & P & $\begin{array}{c}\text { Odds } \\
\text { ratio }\end{array}$ \\
\hline Woman & $-0,630$ & 0,223 & 7,989 & 1 & $\mathbf{0 , 0 0 5 *}$ & 0,533 \\
\hline Age & & & 3,902 & 3 & $\mathbf{0 , 2 7 2}$ & \\
\hline Under and 30 & 0,635 & 0,355 & 3,195 & 1 & $\mathbf{0 , 0 7 4}$ & 1,888 \\
\hline $31-35$ & 0,170 & 0,336 & 0,256 & 1 & $\mathbf{0 , 6 1 3}$ & 1,185 \\
\hline $36-40$ & 0,295 & 0,329 & 0,807 & 1 & $\mathbf{0 , 3 6 9}$ & 1,344 \\
\hline Married & 0,570 & 0,291 & 3,835 & 1 & $\mathbf{0 , 0 5 0} *$ & 1,768 \\
\hline Number of dependents & & & 5,266 & 2 & $\mathbf{0 , 0 7 2}$ & \\
\hline
\end{tabular}

${ }^{4}$ Appendix

${ }^{5}$ Education level variable wasn't included in the model due to the lack of enough number of observations in each category. On the other hand, since financial literacy points increases with education as we expected, integrity of the analysis is preserved. 
Havva SERIM \& Fahriye ÖZTÜRK, 2021 Cilt: 22, Sayl: 2, ss.480-503.

\begin{tabular}{|c|c|c|c|c|c|c|}
\hline None & 0,737 & 0,358 & 4,236 & 1 & $0,040 *$ & 2,090 \\
\hline $1-2$ & 0,141 & 0,291 & 0,237 & 1 & 0,626 & 1,152 \\
\hline Income & & & 2,136 & 4 & 0,711 & \\
\hline Under and $4000 \mathrm{TL}$ & 0,588 & 0,415 & 2,005 & 1 & 0,157 & 1,800 \\
\hline $4001-6000 \mathrm{TL}$ & 0,204 & 0,345 & 0,349 & 1 & 0,555 & 1,226 \\
\hline 6001-8000 TL & 0,160 & 0,343 & 0,218 & 1 & 0,641 & 1,173 \\
\hline 8001-10000 TL & 0,120 & 0,339 & 0,125 & 1 & 0,724 & 1,127 \\
\hline Financial Literacy Level & $-0,007$ & 0,004 & 2,582 & 1 & 0,108 & 0,993 \\
\hline Procrastination & $-0,080$ & 0,148 & 0,294 & 1 & 0,588 & 0,923 \\
\hline Complexity perception & 0,335 & 0,156 & 4,594 & 1 & $\mathbf{0 , 0 3 2 *}$ & 1,398 \\
\hline Buck passing & $-0,159$ & 0,192 & 0,686 & 1 & 0,407 & 0,853 \\
\hline Public authority endorsement effect & $-0,523$ & 0,139 & 14,158 & 1 & $0,000 *$ & 0,593 \\
\hline Constant & 1,064 & 0,711 & 2,242 & 1 & 0,134 & 2,897 \\
\hline -2 Log likelihood & & \multicolumn{4}{|c|}{ Nagelkerke $\mathrm{R}^{2}$} & \\
\hline 523,207 & 0,100 & \multicolumn{4}{|l|}{0,138} & \\
\hline
\end{tabular}

According to the logistic regression results, gender, marital status, number of dependents, complexity perception and public authority endorsement effect are statistically significant on IRS decisions with AE.

When the statistically significant demographic variables are analyzed, it is seen that women $47 \%$ less likely to opt out than men. Although this finding contradicts with Brown et al. (2012; 2016), it is an expected result because women are more financially literate in these studies. On the other hand, Madrian and Shea (2001) and Aksoy (2019) also find women's probability of opt in is higher than men. Therefore, considering that financial literacy of women is lower than men in the present study, that is an expected result. The probability of opt out is 1,7 times more than single people. Aksoy (2019) sets forth similar result and she explains that the expenditures of spouses and children might require more consumption expenditure and thus reduce their saving ability. However, we also find that opt out rates of people with zero dependents was 2,09 times more than of people with at least 3 dependents, which required other explanations. We think the fact that people with zero dependents are much younger and have higher education levels than people with at least 3 dependents in our sample might be effective in this result. In addition, Brown et al. (2016) obtains that people with children are more likely to stick with default option. For this reason, we suggest that it is possible to obtain detailed and more valid results related to marital status by increasing categories such as married with children, married with no children, divorced and with children.

For the behavioral construct analysis, we see that 1 unit increase in complexity perception increase the probability of opt out from IRS with AE 1,40 times. This finding contradicts with behavioral economics' assumption arguing that default options are effective when people find the decision problem complex. So, why do public employees in Ankara tend to leave the system as they find it complex? This might be resulted from switching to automatic enrollment too early not allowing time to them to comprehend, as stated in other studies for Turkey. On the other hand, public authority endorsement effect turned out to be significant, as predicted by behavioral 


\section{HOW DO DEFAULTS AFFECT BEHAVIOR OF INDIVIDUAL RETIREMENT: EVIDENCE FROM ANKARA}

economics theory. Accordingly, 1 unit increase of endorsement effect reduces the possibility of opting out by $40 \%$. Therefore, it is fair to say that for the sample in this study, the motivation to stay in IRS with AE is to take this policy as public authority recommendation.

When we also consider other related studies, the fact that IRS is perceived complex and public authority endorsement effect is determinative is not surprising. For Turkey, it is highlighted in several studies that Turkey switched to IRS with AE before providing adequate information to society (Gülay et al., 2017; Kocabıyık and Küçükçakal, 2018; Rudolph, 2019). On the other hand, the concern about the returns of accumulations in IRS is likely to stem from the failures in the management of the savings made by public guidance in the past years (Aksoy, 2019). For this reason, it is seen that the public authority plays a major role in providing necessary information and education as well as ensuring the confidence in the system. As a matter of fact, based on the finding that public authority endorsement effect is determinative in opt in decisions, the trust in the public authority is important for the success of this policy.

This empirical research is one of the first studies that analyzes why AES policy affects retirement saving behavior from a behavioral economics perspective for a sample from Turkey. Therefore, it has certain limitations and shortcomings. In this regard, we recommend conducting the study for a larger sample, private sector employees and heterogeneous groups with detailed demographic characteristics. Although, we find that income, age, and financial literacy variables are not statistically significant, that may vary for different samples. Because, as Sunstein (2017b) states, when preferences of a society are too much heterogeneous, default options might not work. In this case, it may be necessary to design default options (such as personalized default options) that vary according to the relevant group. In addition, other related behavioral constructs should be analyzed according to the sample. For example, in research with private sector employees, endorsement effect needs to be analyzed on the basis of employers. Another important is sue is related to the options regarding the amount of contribution deducted from salaries and various funds in the plans. Table 5 illustrates this situation for the sample.

Table 5: Comparison of Financial Literacy and Behavioral Constructs by Portfolio Preferences

\begin{tabular}{|c|c|c|c|c|c|c|}
\hline \multicolumn{2}{|c|}{ Portfolio Preferences in AES } & $\mathbf{n}$ & Avg. & S.d. & $\mathbf{t}$ & $\mathbf{p}$ \\
\hline \multirow{2}{*}{$\begin{array}{l}\text { Financial Literacy } \\
\text { Level }\end{array}$} & My own choices & 38 & 79,47 & 23,47 & \multirow{2}{*}{3,746} & \multirow{2}{*}{0,000} \\
\hline & Default option & 120 & 61,67 & 31,18 & & \\
\hline \multirow{2}{*}{ Procrastination } & My own choices & 38 & 2,27 & 0,83 & \multirow{2}{*}{$-1,287$} & \multirow{2}{*}{0,200} \\
\hline & Default option & 120 & 2,50 & 1,02 & & \\
\hline \multirow{2}{*}{ Complexity $\mathbf{P}$. } & My own choices & 38 & 1,97 & 0,80 & \multirow{2}{*}{$-1,874$} & \multirow{2}{*}{0,063} \\
\hline & Default option & 120 & 2,27 & 0,86 & & \\
\hline \multirow{2}{*}{ Buck-passing } & My own choices & 38 & 1,74 & 0,52 & \multirow{2}{*}{$-2,887$} & \multirow{2}{*}{0,005} \\
\hline & Default option & 120 & 2,08 & 0,89 & & \\
\hline \multirow{2}{*}{$\begin{array}{l}\text { Public A. Endorsement } \\
\text { Effect }\end{array}$} & My own choices & 38 & 2,32 & 0,99 & \multirow{2}{*}{$-0,863$} & \multirow{2}{*}{0,390} \\
\hline & Default option & 120 & 2,48 & 0,97 & & \\
\hline
\end{tabular}


Havva SERIMM \& Fahriye ÖZTÜRK, 2021 Cilt: 22, Sayl: 2, ss.480-503.

*People who actively choose for fund types have higher financial literacy level $(79,47)$. People who stick with the automatic portfolio allocation have higher buck-passing tendency $(2,08)$.

In this study, we found out that financial literacy and behavioral constructs are not effective in contribution rate preferences, but financial literacy and buck passing are effective on portfolio preferences by hypothesis testing. Accordingly, those who make active decisions for portfolio allocation have higher financial literacy and low buck passing tendency. The fact that those who tend to buck passing keep their savings in defaults option, indicates that automatic portfolio allocation options should be carefully designed in order not to cause financial loss in returns. In this study, we found that procrastination tendency, which is frequently suggested as the main reason for why automatic strategies are effective, is not determinative. That might be resulted from using different tools to measure procrastination and the differences between the default option strategies in each study. Last but not least, adding questions such as, to what extent the state contribution would be more encouraging, whether having another pension contract of those who opted in and related to peer effects, has potential to make future research more comprehensive. 


\section{HOW DO DEFAULTS AFFECT BEHAVIOR OF INDIVIDUAL RETIREMENT: EVIDENCE FROM ANKARA}

\section{CONCLUSION}

One of the most intriguing contributions of economics and psychology cooperation is related to private pension saving behavior. Drawing on psychological insights such as bounded rationality, inertia, and procrastination, we see that default options as a behavioral tool in economics are very effective and widely used in changing individual retirement saving behavior. Having found out that there are many studies show default options help to enroll employees in IRS and thus enabled them to increase their savings, in other words, there are many studies focusing on the outputs of the policy, but the limited empirical research on how this policy works, we focused on which behavioral constructs are effective on default options. In accordance with the theoretical and empirical studies, we identified variables which we envisioned that are effective on automatic enrollment policy to IRS in Turkey. Noting that Turkey is one of the rare countries that implemented AE to IRS at nationwide and behavior of public and private sector employees in context of individual retirement saving would vary, we studied with public employees as a first step. In this context, we collected data from employees of public institutions and organizations in Ankara through face-to-face surveys in May 2019. A total of 434 people were interviewed. Due to the law on protection of personal data, we couldn't use the random sampling method, which enables generalization regarding the population, However, by choosing the maximum variation sampling method in purposive sampling, we had reached employees from different institutions and organizations and different socio-economic levels as much as possible. Thus, we had aimed to shed light on the views and behaviors of public employees in the country regarding the individual pension system with automatic participation, through the public employees of Ankara.

The questionnaire used in the study consists of three parts. In the first part, we acquired data regarding socio-demographic characteristics of the employees, opt in or opt out choices of the individual pension contract with automatic participation and the reasons for those choices. In the second part, there are five questions prepared to determine the financial literacy levels of employees. In the third part, in accordance with the related literature, statements that aimed to measure four behavioral constructs take place. Thus, we obtained complexity perception of the decision problem, procrastination, buck-passing and public authority endorsement variables. As well as in Turkey in general, the majority of respondents (64\%) were found to be opted out. The main reasons for opting out are concerns about the returns of savings and saving in different ways for the retirement period. Participants were mostly accurate when responding to general financial questions, it is noted that at least correct answers given to questions regarding the questions of private pension system in Turkey. After acquiring the variables, we made logistic regression analysis to understand how AE to IRS works. The socio-demographic and behavioral construct variables and financial literacy scores examined in the model were taken as independent variables, and the opt in/opt out choices as the dependent variable. According to the results of the model, among the demographic variables gender, marital status, and the number of dependents in the household and among the behavioral constructs variables complexity perception of the decision problem and public authority endorsement effect were significant. Explanation of AE to IRS behavior with two behavioral constructs for the sample in the study, provided important implications for the applied policy. Contrary to what the behavioral economic theory predicts, public employees in Ankara did not stay in the system because they found the IRS complex; they preferred to opt out the system. Given the low level of financial literacy score for IRS in Turkey, it is fair to say that employees weren't informed enough about the policy in question, therefore, they chose to stay away from IRS finding the system complicated. On the other hand, the fact that the effect of public authority endorsement effect determines the decision to stay in the system is in 
Havva SERIM \& Fahriye ÖZTÜRK, 2021 Cilt: 22, Sayl: 2, ss.480-503.

line with the argument of behavioral economics that the default options could be taken as a recommendation. Implementation of the policy at the national level as a public policy is likely to allow employees to consider this as proposal submitted by public authorities. In this regard, we addressed that the public authority has a great role in making the automatic enrollment strategy more successful.

This study is one of the first empirical studies to examine why default options affect private pension saving from a behavioral economics perspective in Turkey. Therefore, it is subject to certain constraints and shortcomings. In this context, it is recommended that the research could be carried out with a larger sample, private sector employees and with heterogeneous groups, and therefore expanded by including more different behavioral insights. In addition, we suggest that testing the effects of automatic options regarding the contribution rates and portfolio allocations would enable more effective policy designs. 


\section{HOW DO DEFAULTS AFFECT BEHAVIOR OF INDIVIDUAL RETIREMENT: EVIDENCE FROM ANKARA \\ REFERENCES}

Aksoy, E. E. (2019). "Individual Factors Affecting the Participation of Turkish People in the New Individual Pension System". In Behavioral Finance and Decision-Making Models, IGI Global (Ed.), 104-116.

Alvi, M. (2016). A Manual for Selecting Sampling Techniques in Research. Munich Personal RePEc Archive Paper No. 70218. https://mpra.ub.uni-muenchen.de/70218/1/MPRA, Last accessed: 2 February 2019

Aydın, A. E., \& Selçuk, E. A. (2017). Türkiye'de Bireysel Emeklilik Sistemine Katılım Kararını Etkileyen Faktörler. Finans Politik \& Ekonomik Yorumlar, 54(632), 27-37.

Benartzi, S., \& Thaler, R. H. (2007). Heuristics and Biases in Retirement Savings Behavior. Journal of Economic Perspectives, 21(3), 81-104.

Beshears, J., Choi, J. J., Laibson, D., \& Madrian, B. C. (2008). "The Importance of Default Options for Retirement Saving Outcomes: Evidence from the United States". In Lessons from Pension Reform in the Americas, S.J. Kay ve T. Sinha (Ed.). Oxford University Press: US, 59-87.

Beshears, J., Choi, J. J., Laibson, D., \& Madrian, B. C. (2018). "Behavioral household finance". In Handbook of Behavioral Economics: Applications and Foundations I. Elsevier-North Holland: New York, 177-276.

Blumenstock, J., Callen, M., \& Ghani, T. (2018). Why Do Defaults Affect Behavior? Experimental Evidence from Afghanistan. American Economic Review, 108(10), 2868-2901.

Brown, J. R., \& Previtero, A. (2014). Procrastination, Present-Biased Preferences, and Financial Behaviors. Unpublished Working Paper, University of Illinois at Urbana-Champaign and University of Western Ontario.

Brown, J. R., Farrell, A. M., \& Weisbenner, S. J. (2012). The Downside of Defaults. NBER Retirement Research Center Paper No. NB 11-01.

Brown, J. R., Farrell, A. M., \& Weisbenner, S. J. (2016). Decision-Making Approaches and the Propensity to Default: Evidence and Implications. Journal of Financial Economics, 121(3), 477-495.

Carroll, G. D., Choi, J. J., Laibson, D., Madrian, B.C., \& Andrew, M. (2009). Optimal Defaults and Active Decisions. The Quarterly Journal of Economics, 124(4), 1639-1674.

Chetty, R., Friedman, J. N., Leth-Petersen, S., Nielsen, T. H., \& Olsen, T. (2014). Active vs. Passive Decisions and Crowd-out in Retirement Savings Accounts: Evidence from Denmark. The Quarterly Journal of Economics, 129(3), 1141-1219.

Choi, J. J., Laibson, D., Madrian, B. C., \& Metrick, A. (2002). Defined Contribution Pensions: Plan Rules, Participant Choices, and the Path of Least Resistance. Tax policy and the Economy, 16, 67-113.

Choi, J. J., Laibson, D., Madrian, B. C., \& Metrick, A. (2004). For Better or for Worse: Default Effects and 401 (k) Savings Behavior. National Bureau of Economic Research (Perspectives on the Economics of Aging), University of Chicago Press, 81-126. 
Havva SERIMM \& Fahriye ÖZTÜRK, 2021 Cilt: 22, Sayl: 2, ss.480-503.

Pension Monitoring Center. (2018). Bireysel Emeklilik Sistemi Gelişim Raporu 2017. https://www.egm.org.tr/bes2017gr/Flipbook/mobile/index.html\#p=I, Last accessed: 2 March 2019

Pension Monitoring Center. (2019). Statistics, OKS'ye Giren Çalışanların OKS'ye Giriş Anında BES Sözleşmesi Olup Olmadiğı, Last accessed, 30 March 2019 https://www.egm.org.tr/bilgi-merkezi/istatistikler/

Goda, G. S., Levy, M. R., Manchester, C. F., Sojourner, A., \& Tasoff, J. (2018). Mechanisms Behind Retirement Saving Behavior: Evidence from Administrative and Survey Data. TIAA Institute Research Dialogue, 140.

Goda, G. S., Manchester, C. F., \& Sojourner, A. J. (2014). What will my account really be worth? Experimental Evidence on How Retirement Income Projections Affect Saving. Journal of Public Economics, 119, 80-92.

Gülay, T., Işık, M., \& Öztürk, M. (2017). Türkiye'de Bireysel Emeklilik Sistemi ve Akademisyenlerin Otomatik Katılıma Bakış Açılarına İlişkin Bir Analiz: Süleyman Demirel Üniversitesi Örneği. İş ve Hayat, 3(6), 179-205.

Johnson, E. J., \& Goldstein, D. G. (2003). Do Defaults Save Lives? Science, 302, 1338-1339.

Johnson, E., Hershey, J., Meszaros, J., \& Kunreuther, H., (1993). Framing, Probability Distortions, and Insurance Decisions. Journal of Risk and Uncertainty, 7, 35-51.

Kocabıyık, T., \& Küçükçakal, Z. (2018). Türkiye'de Bireysel Emeklilik Sistemi ve Çalışanların Otomatik Kat1lımdan Ayrılma Nedenleri: Isparta İlinde Bir Uygulama. Journal of Life Economics, 5(4), 233-254.

Lusardi, A., \& Mitchell, O.S. (2005). Financial Literacy and Planning: Implications for Retirement Wellbeing. Working Paper No. WP 2005-108. Ann Arbor, MI: University of Michigan Retirement Research Center.

MacLeod, P., Fitzpatrick, A., Hamlyn, B., Jones, A., Kinver, A., \& Page, L. (2012). Attitudes to Pensions: The 2012 Survey. Department of Work and Pension: Research Report, 813.

Madrian, B. C. (2012). "Matching Contributions and Savings Outcomes: A Behavioral Economics Perspective". In Matching Contributions for Pensions: A Review of International Experience, R. Hinz, R. Holzmann, D. Tuesta and N. Takayama (Ed). The World Bank, 289-309.

Madrian, B. C., \& Shea, D. F. (2001). The Power of Suggestion: Inertia in 401 (K)Participation and Savings Behavior. The Quarterly Journal of Economics, 116(4), 1149-1187.

Mann, L., Burnett, P., Radford, M., \& Ford, S. (1997). The Melbourne Decision Making Questionnaire: An instrument for Measuring Patterns for Coping with Decisional Conflict. Journal of Behavioral Decision Making, 10(1), 1-19.

McCalley, LT. (2006). From Motivation and Cognition Theories to Everyday Applications and Back Again: The Case of Product-Integrated Information and Feedback. Energy Policy, 34(2), 129-37.

Mitchell, O. S., \& Utkus, S. P. (2004). Lessons from Behavioral Finance for Retirement Plan Design. Pension Design and Structure: New Lessons from Behavioral Finance, 18(1), 8294. 


\section{HOW DO DEFAULTS AFFECT BEHAVIOR OF INDIVIDUAL RETIREMENT: EVIDENCE FROM ANKARA}

OECD (2009). Pensions at a Glance 2009: Retirement-Income Systems in OECD Countries, OECD Publishing, Paris, https://doi.org/10.1787/pension glance-2009-en, Last accessed 4 February 2018

Özdevecioğlu, M. (2002). Kamu ve Özel Sektör Yöneticileri Arasındaki Davranışsal Çalışma Koşulları ve Kişilik Farklılıklarının Belirlenmesine Yönelik Bir Araştırma. Erciyes Üniversitesi Íktisadi ve İdari Bilimler Fakültesi Dergisi, (19), 115-134.

Özen, Y., \& Gül, A. (2007). Sosyal ve Eğitim Bilimleri Araştırmalarında Evren-Örneklem Sorunu. Atatürk Üniversitesi Kazım Karabekir Eğitim Fakültesi Dergisi, (15), 394-422.

Palinkas, L. A., Horwitz, S. M., Green, C. A., Wisdom, J. P., Duan, N., \& Hoagwood, K. (2015). Purposeful Sampling for Qualitative Data Collection and Analysis in Mixed Method Implementation Research. Administration and Policy in Mental Health, 42(5), 533-544.

Rinaldi, A. (2011). Pension Awareness and Nation-Wide Auto-Enrolment: The Italian Experience. CERP Working Paper, 104(11), 1-22.

Rooij, van M., \& Teppa, F. (2014). Personal Traits and Individual Choices: Taking Action in Economic and Non-economic Decisions. Journal of Economic Behavior \& Organization, 100, 33-43.

Rudolph, H. P. (2016). Building Voluntary Pension Schemes in Emerging Economies. World Bank Group Policy Research Working Paper No. 7779, 1-31.

Rudolph, H. P. (2019). Pension Funds with Automatic Enrollment Schemes: Lessons for Emerging Economies. World Bank Group Policy Research Working Paper No. 826, 1-31.

State Personnel Presidency (2018). Kamu Personel Ístatistikleri (Ocak), Ankara.

Sunstein, C. R. (2014). Nudging: a very Short Guide. Journal of Consumer Policy, 37(4), 583-588.

Sunstein, C. R. (2017a). Human Agency and Behavioral Economics: Nudging Fast and Slow. Palgrave macmillan: USA.

Sunstein, C. R. (2017b). Default Rules Are Better than Active Choosing (often). Trends in Cognitive Sciences, 21(8), 600-606.

Sunstein, C. R., \& Reisch, L. A. (2016). "Behaviorally Green: Why, Which and When Defaults Can Help". In New Perspectives for Environmental Policies Through Behavioral Economics, F. Beckenbach ve W.Kahlenborn (Ed.) Springer: Switzerland, 161-194.

Thaler, R. H., \& Sunstein, C.R (2008). Nudge: Improving Decisions about Health, Wealth, and Happiness. Yale University Press..

Turkish Ministry of Economy, Davranışsal Kamu Politikaları ve Yeni Nesil Teknolojiler Daire Başkanlığı, (2018). Senin Kararın!mı? Kamu Politikası Tasarımında Davranışsal Yaklaşım. https://ticaret.gov.tr/data/5b9623ea13b8761ce82c5e34/senin_kararin_mi.pdf, Last accessed: 8 February 2019

Willem, A., De Vos, A., \& Buelens, M. (2007). Differences Between Private and Public Sector Employees’ Psychological Contracts. Working paper. Belgium: Ghent University, Faculty of Economics and Business Administration, Department Management and Entrepreneurship, Tweekerkenstraat 2, 9000. 
Havva SERIM \& Fahriye ÖZTÜRK, 2021 Cilt: 22, Sayl: 2, ss.480-503.

\section{APPENDIX}

Table 6: Coefficient of Skewness and Kurtosis

\begin{tabular}{llcc}
\hline & $\mathrm{n}$ & Skewness & Kurtosis \\
\hline Financial Literacy & 434 & $-0,595$ & $-0,512$ \\
\hline Procrastination & 434 & 0,696 & 0,503 \\
\hline Complexity perception & 434 & 0,659 & 0,421 \\
\hline Buck-passing & 434 & 1,165 & 2,677 \\
\hline Public authority endorsement effect & 434 & 0,462 & $-0,020$ \\
\hline
\end{tabular}

*Normal distribution

Table 7: Reliability Analysis for Financial Literacy

\begin{tabular}{ll}
\hline Cronbach's Alfa & 0,627 \\
\hline KR-20 Value & 0,629 \\
\hline
\end{tabular}




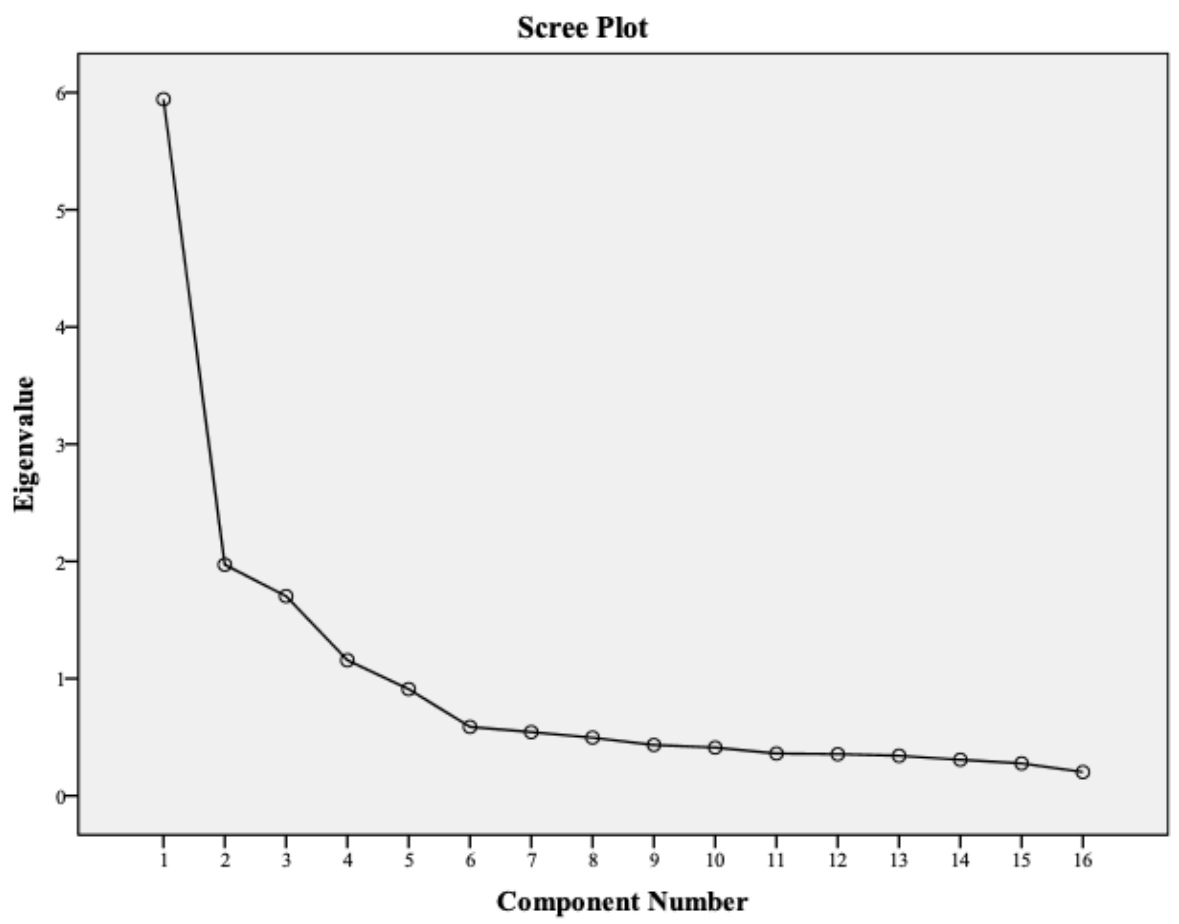

Factor Analysis Results

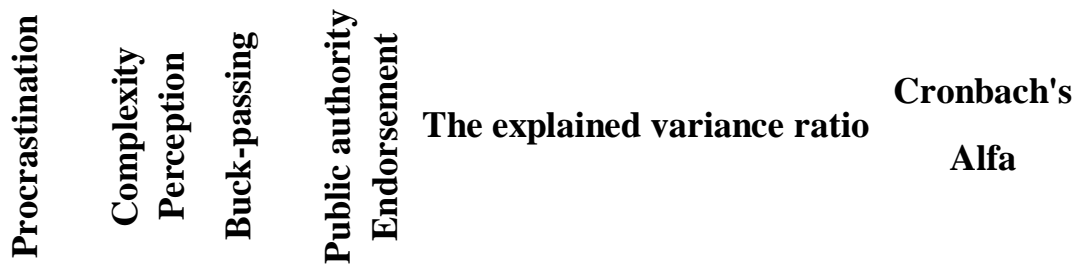

When I have to make a decision, I

wait a long time before I start $\quad 0,835$

thinking about it.

I postpone making a decision until its too late.

0,794

I spend a lot of time on trivial matters until I reach the final

decision.

I postpone taking action even after I have made a decision.

0,700

The issue of private pension seems so complicated to me that I cannot understand what is best 0,855 17,826 $\mathbf{0 , 8 3 0}$ thing to do. 
Havva SERIM \& Fahriye ÖZTÜRK, 2021 Cilt: 22, Sayl: 2, ss.480-503.

Dealing with the private pension

system scares me.

0,831

I avoid thinking about the

individual pension system.

0,815

Whatever the subject is, I avoid making decisions.

0,628

I usually prefer to leave it up to others to make decisions on any matter.

If a decision is to be made by me or another person, I would prefer the other person to make the decision.

I don't like to take responsibility for any decision.

0,777

17,617 $\mathbf{0 , 7 8 6}$

I prefer people more

knowledgeable than me to decide for me.

If the public authority has decided on my behalf, this is the best decision for me.

Because the public authority is more knowledgeable than me, it takes a decision in my favor.

I rely on public authority when I have to make a decision.

0,597

Total

68,728

$\mathbf{0 , 8 7 1}$

*As a result of the factor analysis, "I do not make a decision on any issue unless it is really necessary." question was removed from the scale due to crossing over. Accordingly, it was determined that the scale consists of 15 questions and 4 factors. 
HOW DO DEFAULTS AFFECT BEHAVIOR OF INDIVIDUAL RETIREMENT: EVIDENCE FROM ANKARA

Table 8: Correlation Matrix

\begin{tabular}{|c|c|c|c|c|c|c|}
\hline & & $\begin{array}{c}\text { Financial } \\
\text { Literacy } \\
\text { Level }\end{array}$ & Procrastination & Complexity $\mathbf{P}$. & $\begin{array}{c}\text { Buck- } \\
\text { passing }\end{array}$ & $\begin{array}{c}\text { Public A. } \\
\text { Endorsement } \\
\text { Effect }\end{array}$ \\
\hline \multirow{2}{*}{$\begin{array}{l}\text { Financial Literacy } \\
\text { Level }\end{array}$} & $\mathrm{r}$ & 1 &,$- 150^{* *}$ &,$- 373^{* *}$ &,$- 142^{* *}$ &,$- 147^{* *}$ \\
\hline & $\mathrm{p}$ & & 0,002 & 0,000 & 0,003 & 0,002 \\
\hline \multirow{2}{*}{ Procrastination } & $\mathrm{r}$ & & 1 &, $319^{* *}$ &, $553^{* *}$ &, $332^{* *}$ \\
\hline & $\mathrm{p}$ & & & 0,000 & 0,000 & 0,000 \\
\hline \multirow{2}{*}{ Complexity P. } & $\mathrm{r}$ & & & 1 & $407^{* * *}$ &, $249^{* *}$ \\
\hline & $\mathrm{p}$ & & & & 0,000 & 0,000 \\
\hline \multirow{2}{*}{ Buck-passing } & $\mathrm{r}$ & & & & 1 &, $381^{* *}$ \\
\hline & $\mathrm{p}$ & & & & & 0,000 \\
\hline \multirow{2}{*}{$\begin{array}{l}\text { Public A. } \\
\text { Endorsement } \\
\text { Effect }\end{array}$} & $\mathrm{r}$ & & & & & 1 \\
\hline & $\mathrm{p}$ & & & & & \\
\hline
\end{tabular}

* There is no strong linear relationship (high degree of correlation) between these independent variables.

Table 9: Statistical Convenience Tests for Using Behavioral Constructs Variables as Scales

\begin{tabular}{llr}
\hline KMO & & 0,872 \\
\hline Bartlett Test & $X^{2}$ & 3293,529 \\
& $\mathrm{Sd}$ & 120 \\
& $\mathrm{P}$ & 0,000 \\
\hline
\end{tabular}

$* \mathrm{KMO}>0,500 ; \mathrm{p}<0,05$ 
Havva SERIM \& Fahriye ÖZTÜRK, 2021 Cilt: 22, Sayl: 2, ss.480-503.

\section{EXTENDED ABSTRACT}

Main contribution of economics and psychology cooperation to saving practices within the context of behavioral economics is related to individual retirement saving behavior. Also, it is seen that the default options are effective and widely used in changing the individual retirement savings behavior. Encouraging individual pension systems are important due to both its macroeconomic outputs such as increasing total savings and easing the burden on the younger population and microeconomic outputs such as maintaining current living standards during retirement periods. However, despite the importance of the individual pension system for employees, many employees do not make enough use of the private pension opportunities provided by their employers or start saving for retirement too late. In this context, many automatic strategies using default options like automatic enrollment, automatic escalation and automatic portfolio allocation are developed to increase employee participation and savings in the private pension system (Madrian ve Shea, 2001; Choi et. 2002; 2004; Mitchell and Utkus, 2004; Benartzi and Thaler, 2007; Madrian, 2012). Thus, default options applied in the private pension system might help people to execute the savings they want to make automatically without having to think constantly about the issue.

It is observed that New Zealand, Italy, United Kingdom and Turkey have implemented the automatic enrollment private pension policy nationwide. The widespread implementation of this policy, which considers the insights of behavioral economics and also implementation in the country, has motivated the study. Despite the fact that there are many studies that focus on the outcomes of the policy, which reveal that the default options include employees in their private pension plans and thus increase their savings, empirical research on how this policy works is limited, we focus on how the default options are effective. After examining the theoretical predictions of behavioral economics on the subject, the relevant literature was searched. In line with the theoretical and empirical analysis, the variables that are thought to be effective in the automatic enrollment strategy in private pension implemented in Turkey were determined. Automatic enrollment in the private pension system as a default option was searched for the sample of Ankara province due to time and cost constraints. Since it is thought that the behavior of public and private sector employees in the context of savings will vary, public employees selected in this study. In this context, data were collected from the employees of public institutions and organizations in Ankara through a face-to-face survey study in the period of May 2019. A total of 434 people were interviewed. In the selection of the sample, the random method, which enables generalization, could not be used due to the personal data protection law. However, by choosing the maximum diversity method in purposive sampling, employees aged 45 and under were reached from as many different institutions and organizations and socio-economic levels as possible. Thus, it is aimed to shed light on the views and behaviors of public employees in the country regarding the automatic participation private pension system through public employees in Ankara.

The questionnaire used in the study consists of three parts. In the first part, there are questions and statements to determine the demographic characteristics of the employees, the continuation/termination status of the auto-enrollment private pension contract and the reasons for this. In the second part, there are five questions prepared to determine the financial literacy levels of the employees. In the third part, there are statements prepared on a 5-point Likert scale to measure four behavioral constructs that are thought to be effective in automatic private retirement behavior in Turkey in line with the relevant literature. In this context, the variables of complexity perception of the decision problem, procrastination, buck-passing, and public authority endorsement effect were obtained. As is the case across Turkey, it was observed that the vast 


\section{HOW DO DEFAULTS AFFECT BEHAVIOR OF INDIVIDUAL RETIREMENT: EVIDENCE FROM ANKARA}

majority of the participants $(64 \%)$ terminated their auto-enrollment private pension contracts. The main reasons for the termination of the contract were the concern about the returns of savings and the different forms of saving for the retirement period. It has been found that the main reasons for the continuation are the fact that it is an opportunity to save and that the $25 \%$ state contribution is encouraging. After analyzing the related variables, logistic regression analysis was conducted to investigate how the automatic enrollment policy became functional. The demographic and behavioral construct variables and financial literacy scores examined in the model were included as independent variables, and the continuation/termination status of the auto-enrollment of the contract as the dependent variable. According to the results of the model, demographic variables such as gender, marital status, and the number of dependents in the household and behavioral construct variables such as, public authority endorsement effect and complexity perception are significant.

When the statistically significant demographic variables are examined, it is seen that women are $47 \%$ less likely to opt out than men. This finding is consistent with Brown et al. (2012; 2016), it is an expected result since women have more financial information than men in the mentioned studies. On the other hand, Madrian and Shea (2001) and Aksoy (2019) who carried out a similar study in Turkey, find that women are more likely to opt in the system than men. Therefore, considering that the financial literacy of women is lower than that of men in this study, it is seen that this finding is compatible with expectations in this sense. It is seen that married people are 1.77 times more likely to opt out than single people. Aksoy (2019) reaches a similar conclusion and explains this as the fact that the needs of spouses and children of married people cause more consumption expenditures and thus reduce their saving power. On the other hand, Brown et al. (2016) finds that people with children are more likely to stay in the default option. For this reason, it might be important to include categories, such as married ones without a child, married with children, divorced ones with children etc.

According to the analysis, the effect of complexity perception and public authority endorsement from behavioral constructs are statistically significant. An increase by 1 unit in the perception of complexity increases the probability of opt out by 1.40 times. This finding contradicts behavioral economics argument that the automatic enrollment will be effective when people find the private pension plans complex. It is understood that for the public employees in the city of Ankara, the complexity perception of system led them to opt out. It is possible that the reason for this is, as stated in other studies, that Turkey implemented this policy before providing sufficient information. Public authority endorsement effect, on the other hand, turned out to be significant, as predicted by behavioral economic theory. Accordingly, a 1-unit increase in the public authority endorsement effect reduces the probability of opt out by $40 \%$. Therefore, it is fair to say that the motivation for opting in for the sample in the study is to perceive the policy as the advice of the public.

This empirical research is one of the first studies in the literature from Turkey to examine why the automatic enrollment strategy affects retirement savings from a behavioral economics perspective. Therefore, it has certain limitations and deficiencies. In this context, it is recommended that the research be carried out for a larger sample, private sector employees and different heterogeneous groups with detailed demographic characteristics. Although the variables of income, age and financial literacy were not found statistically significant in this study, it is predicted that the findings may vary in different samples. Because, as stated by Sunstein (2017b), the default options are not successful when the preferences in the society show too much heterogeneity. In this 
Havva SERİM \& Fahriye ÖZTÜRK, 2021 Cilt: 22, Sayl: 2, ss.480-503.

case, it may be necessary to design customized default options (personalized default options) that vary according to each related group. In addition, behavioral insights to be researched should be diversified according to the selected sample. Also, it might be very informative to study the behaviors of people who opt in the plan without making any changes in the contribution and fund types. Thus, it is anticipated that important information might be obtained regarding the automatic escalation and automatic portfolio allocation strategies that may be implemented in the future. 